\title{
Notes on the Action of some Aniline Dyes on Vegetable Tissues
}

John M. Macfarlane B.Sc.

To cite this article: John M. Macfarlane B.Sc. (1883) Notes on the Action of some Aniline Dyes on Vegetable Tissues, Transactions of the Botanical Society of Edinburgh, 14:1-4, 190-191, DOI: $10.1080 / 03746608309468406$

To link to this article: http://dx.doi.org/10.1080/03746608309468406

曲 Published online: 01 Dec 2010.

Submit your article to this journal \lceil

Llll Article views: 2

Q View related articles $₫$ 


\section{EXPLANATION OF PLATES.}

Plate VII.-Portion of branch of Lepidophloios laricinum bifurcating. Below the point of dichotomy are two cicatrices or tubercles pretty far apart, while above there are several developed in regular order. The lower part of the branch is destitute of tubercles, and exactly resembles an ordinary Lepidophloios; the upper portion with tubercles is what has hitherto been designated Halonia.

PLATE VIII.-Fig. 1. Supposed cone of Lepidophloios laricinum with cone-stalk. The latter, in all probability, articulated with a tubercle of the Halonia branch.

Fig. 2. Isolated cone scale.

Fig. 3. Portion of stem of L. laricinum 3 inches in diameter, natural size.

Fig. 4. Portion of cone-stalk, $\frac{1}{3}$ inch in diameter, magnified.

Fig. 5, $a, b, c$. Stages in the development of the cone.

Notes on the Action of some Aniline Dyes on Vegetable Tissues. By John M. Macfarlane, B.Sc.

(Read 14th July 1881.)

The action of the aniline dyes on vegetable and animal tissues has recently been carefully studied, and the results obtained have proved satisfactory. I now propose recording some of the rnore important methods arrived at.

I. Staining of Laticiferous Vessels. - Every botanist must have experienced the difficulty of obtaining thoroughly good preparations of laticiferous vessels. Sachs* recommends boiling in dilute potash; but, while tolerably good sections may be obtained in this way, several difficulties are encountered. The points to be aimed at in preparing this tissue are $(a)$ the coagulation of the latex, so that it may continue to fill the vessels; (b) the staining of the cut sections, so that the vessels may be distinctly differentiated from the surrounding cellular substance; $(c)$ the successful mounting of these, so that the tint may be permanently retained. The first part of the process is best accomplished by obtaining, for example, a large and entire root of Scorzonera, so that extensive bleeding may be prevented. A suitable

* Text-book of Botany, p. 110. 
sized bottle being filled with alcohol, pieces of the root from one to two inches in length are cut, and immediately placed in it. Coagulation of the latex is quickly effected. After lying thus for a week or longer, sections are cut with the hand, or by aid of a microtome. The second point is most important, and on its success the beauty of the object will depend. The sections are placed in alcoholic solution of saffranine, obtained by dissolving 1 part of this dye in 800 parts spirit. After eighteen to twenty-four hours they are removed from the stain and decolorised by washing repeatedly in spirit. It will be found that the stain leaves the cellular tissue rapidly, while it is retained by the latex in the vessels. We will notice lastly the best method for mounting these. While such media as balsam or dammar would cause unnatural contraction, fluids, on the other hand-especially acetic acid solution-are apt to act slightly on the dye. I have found nothing to equal glycerine jelly, as it preserves the tint and is easily worked. II. Double Staining of Stems, \&c.-The dyes usually recommended for this purpose are rosaniline and iodine green; but saffranine and emeraldine are preferable, as the former is, for vegetable tissues, a most permanent dye, while the latter imparts a brighter colour than iodine green.

III. Staining of Cell Contents. - While some aniline dyes act specially on the thickened walls of cells, others are extremely useful for demonstrating the structure of protoplasm. Heliocin and naphthaline in this respect are valuable; and eosin, though not an aniline dye, is equally so. For epidermis cells and ordinary parenchyma the latter is preferable. It is best prepared by dissolving 1 part, in 1200, of alcobol. The specimens are allowed to lie for five minutes in the stain, and are then washed in water and mounted in a cell with acetic acid, or Goadby's solution. The cells of Spirogyra, however, have their minute structure beautifully revealed by treatment with heliocin. The following is the best method to adopt:Decolorise the filaments by placing them in a 1 per cent. solution of chromic acid for two days; add then to the solution 1 part, in 2000, of the dye and shake slightly, so that it may dissolve equally. In an hour the filaments will be ready for examination or permanent preparation. 